\title{
THE BRICS’ CENTRIFUGAL GEOPOLITICAL ECONOMY
}

\author{
P. Bond
}

University of the Witwatersrand, Johannesburg, South Africa

\begin{abstract}
The article is dedicated to the analysis of centrifugal tendencies within the framework of BRICS and to their influence on the processes, proceeding in the system of global world. Factors, which stimulate these tendencies are examined. The author considers that, in spite of positive potential and the notable position, which the countries of BRICS play under the conditions of global crisis phenomena, by their present economic policy they contribute to the sanitation "of imperialism"; activate the negative manifestations of the global "crisis of capitalism". In the author's the opinion multipolarity strengthens the neoliberal nature of institutes, especially in spheres of finances, trade and climate. The corporations, which are based in the countries of BRICS, demonstrate super-exploitation in the course of the accumulation of capital both in their regions and beyond their limits. The article is based on comprehension of documents of international organizations, including UNCTAD, analytics views, sometimes adhering to contrary opinions. The main aim of the author is to prove the possibility to move in positive direction. The article contains the claim to the society of BRICS members to consider summit of BRICS in Johannesburg in 2018 as an invitation for serious discussion of the problems of contemporary global policy.
\end{abstract}

Key words: BRICS, global policy, corporations, Johannesburg, summit, multipolarity

The formation of the Brazil—Russia-India—China—South Africa (BRICS) network in 2009, based on South-South Cooperation and the desire to establish new institutions, has been derailed by self-interest of the dominant member, Beijing. While the Goldman Sachs banker Jim O'Neill began discussing the BRIC countries as $21^{\text {st }}$ century investment opportunities in 2001, this appears in retrospect to be part of the standard Goldman Sachs approach to investment 'churning' (for by 2013 the bank shut down its BRIC fund after poor returns). In 2006, a meeting between BRIC countries took place on the margins of the United Nations General Assembly. However, it was with the global financial crisis that the economic role of the BRICS gained prominence. The crisis confirmed that Western countries were losing power in the world order, especially insofar as financial bailouts and currency printing initially failed to restore growth, leaving the Chinese and Indian economies as drivers of global capitalism.

After two decades of unprecedented growth, it certainly appeared that China's economy would challenge the dominant position of the U.S., Europe and Japan. The G8 countries expanded into the G20 in late 2008 in part to raise $\$ 750$ billion in new resources for the International Monetary Fund (IMF), to stave off world financial meltdown. In 2009, the first BRIC heads-of-state summit took place in Russia, launching a succession of annual gatherings of leaders that gave body and content. South Africa was incorporated as an African member at Beijing's request in 2010, and BRICS went through a process

1 A much longer version of this analysis is being published in Socialist Register 2019. 
of institutional densification, drawing thousands of participants not only for inter-governmental events but also in business, academic, cultural, youth, labor and civil society exchanges.

The Indian National Congress party's loss to the Hindu-nationalist Bharatiya Janata Party (BJP) in 2014 did not disrupt the BRICS, although 2017 border battles between India and China caused enormous concern.

By this time, the Chinese president who gave BRICS muscle, Hu Jintao, was succeeded by Xi Jinping in 2013, and within four years consolidated his power to Maolike levels. Likewise, the control Vladimir Putin exercised in Russia and his allegiance to the BRICS both grew stronger after Crimea events, as the other G7 powers expelled Russia from the G8. Notably, Brazil's 2016 congressional coup d'etat by Michel Temer, which ended Workers Party rule after 13 years, did not substantially affect the BRICS' agenda, nor did a more popular palace-coup replacement of South Africa's President Jacob Zuma (who had served since 2009) by his deputy Cyril Ramaphosa in February 2018, 15 months ahead of schedule. This occurred just five months before South Africa hosted the BRICS summit, with Zuma begging on national television to be permitted to stay through August, "to remove the perception out there that Zuma is being elbowed out"'.

Through all this political turmoil, grand claims have been offered about the way BRICS will rebalance the world and ensure good global governance. This essay considers the opposite, namely that a resurgent imperialism is being facilitated by BRICS politics. This functions in three ways. First, amplified global capitalist crisis tendencies are emanating from centrifugal BRICS economies. Second, multipolarity is amplifying the neoliberal character of multilateral institutions, especially in the spheres of finance, trade and climate politics, as the BRICS gain a seat at the table. Third, in a subimperial manner, BRICS-based corporations are vital forces in super-exploitative accumulation within their respective regions and beyond.

Finally, as seen in Johannesburg in mid-2018, the BRICS serve as an invitation for their societies to talk about global politics much more seriously. In previous works, we have identified ideological positions that help present BRICS through at least a rudimentary class analysis: 'BRICS from above' (the position of governmental and business leaders); 'BRICS from the middle' (the position of the generally pro-BRICS academics, think tanks, NGOs and trade unions); 'BRICS from below' (grassroots movements in struggles within those countries and beyond them, that may one day create strong linkages between struggles and build transnational solidarity). To be sure, another category is each country's pro-Western businesses and their intellectuals (especially strong in South Africa), who remain adherents to old-order capitalism no matter the chaos within U.S.-EU circuits, who still fear the rise of the BRICS [Bond, Garcia 2015].

I conclude by considering aspects of the latter's narratives and strategies.

${ }^{2}$ President Jacob Zuma speaks to SABC News. SA Broadcasting Corporation. 14 February 2018. URL: https://www.youtube.com/watch?v=TJyMfjdnJ2A (accessed 14.07.2018). 


\section{BRICS AS CENTRIFUGAL NOT CENTRIPETAL IN GLOBAL POLITICAL ECONOMY}

Xi's 2015 promise at the BRICS Ufa Summit to boost 'the centripetal force of BRICS nations, tap their respective advantages and potentials and carry out cooperation in innovation and production capacity' now faces extreme political, economic and ecological contradictions. The most obvious geopolitical wedges have been pushed into the BRICS not by Washington, at least for now, but are instead Sino-Indian border conflicts, especially in Pakistani-held Kashmir. There, the transport infrastructure needed by China to link its far western region to the Indian Ocean is a central component of the Belt and Road Initiative. In September 2016, India's Prime Minister Narendra Modi lost a show-down while hosting the Goa 2016 BRICS Summit, when he unsuccessfully tried to have Pakistan declared a terrorist state. Both China and Russia refused.

In mid-2017, an even higher-profile fight unfolded at the site where India and China share a border with Bhutan. When the Chinese built a small road on contested ground, fisticuffs were initiated by Indian soldiers. In late August, just days before the BRICS Xiamen summit was to begin, India backed down and withdrew its troops, but not before Modi's staff hinted he would boycott Xiamen, just as he had China's Belt and Road Summit in May. The Chinese state mouthpiece Global Times ran a column headlined, 'New Delhi may disrupt BRICS Summit to blackmail Beijing.' At the same time, the Chinese government also issued two travel advisories to its citizens visiting India: 'Pay close attention to the local security situation, improve self-protection awareness, strengthen security and reduce unnecessary travel' (the very opposite of the BRICS' stated objective: 'increasing people-to-people links') ${ }^{3}$. In the end, Modi went to Xiamen and there were no further disruptions.

There are deeper economic processes unfolding beneath the geopolitical tensions and rising internal repression. The motors to expand capitalism rapidly - in China and everywhere - were meant to be foreign investment, trade and finance. But even as $\mathrm{Xi}$ praised them, all are running out of steam, or even veering towards collapse amidst soaring indebtedness. Indeed, financial assets invested in other countries fell from a level of 58\% of world GDP in 2008 to just 38\% in 2016, in spite of fast-rising flows into high-risk (high-return) emerging markets and notwithstanding capitalism's growing overall indebtedness. According to the 2018 UN Conference on Trade and Development (UNCTAD) World Investment Report, the BRICS accounted for 19\% of global investment inflows and 23\% of the world GDP in 2017. But Foreign Direct Investment (FDI) into the BRICS fell in 2017 to $\$ 266$ billion, a decline of $\$ 10$ billion from 2016, amidst a global decline of $23 \%$, to $\$ 1.43$ trillion [World Investment Report... 2018].

${ }^{3}$ New Delhi may disrupt BRICS Summit to blackmail Beijing. (2017). Global Times. URL: http://www.globaltimes.cn/content/1061460.shtml (accessed 14.07.2018). 


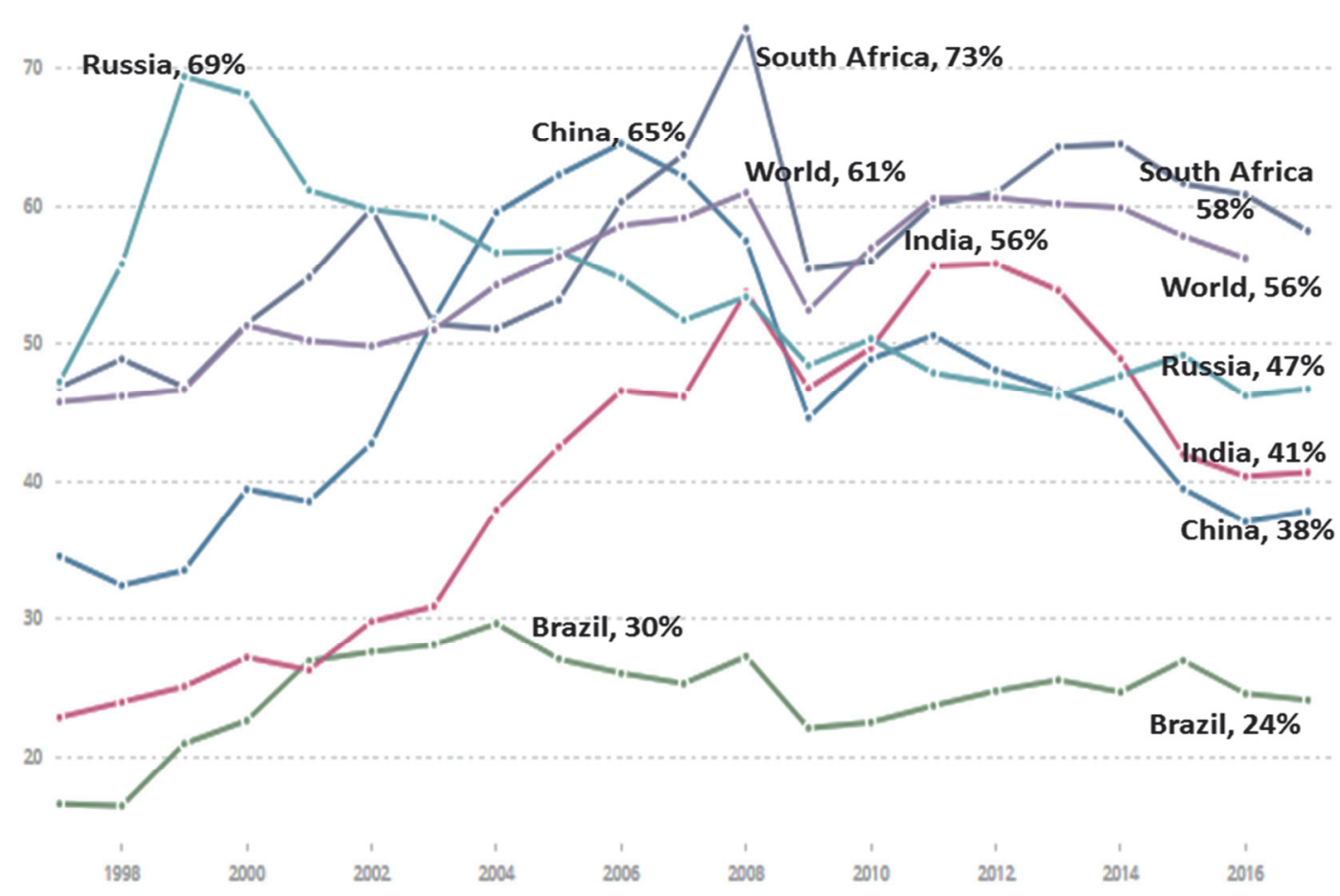

Fig. 1. Rise and fall of BRICS and world trade (imports and exports), 1997-2017: High point ratio and 2017 ratio, as percent of GDP

Source: [World Bank Data Catalogue 2018]

Global trade Sid Verma and Cecile Gutscher peaked at 61\% of world GDP in 2012 and then fell to 2016's 56\%, but the BRICS suffered faster declines in relative trade than the world as a whole (Figure 1). As a Standard Bank economist remarked, "the commercial relevance of the BRICS to one another is minimal. Intra-BRICS trade has actually fallen, from $\$ 342$ billion in 2013 to $\$ 312$ billion in 2017 . Furthermore, taken as a share of their respective trade, the BRICS share has plateaued, after doubling from 6\% in 2003 to $12 \%$ in 2011. In fact, it fell sharply in 2016." As Stevens concluded, "China is exporting manufactured goods to the other BRICS in proportions consistent with their relative GDP, whilst importing mineral products from Russia, Brazil and South Africa, and prepared foodstuff from Brazil" [Stevens 2018]. In addition to unevenness in trade, excessive financialization - both debt and equity over-valuation - is the Achilles Heel. The next recession - which HSBC, Citigroup and Morgan Stanley economists in mid-2017 acknowledged is imminent due to vastly over-priced stock markets and unprecedented corporate indebtedness ${ }^{4}$ - will confirm how capital has become over-exposed locally, even while losing appetite for global markets. This makes credible in this case the mid-2018 warnings of conservative journalist Ambrose Evans-Pritchard: "The world has never been so leveraged, and therefore so sensitive

${ }^{4}$ Verma S., Gutscher C. Wall Street Banks Warn Downturn is Coming. Bloomberg News, 22 August, 2017. URL: https://www.bloomberg.com/news/articles/2017-08-22/wall-street-banks-warnwinter-is-coming-as-business-cycle-peaks (accessed 14.07.2018). 
to a monetary squeeze. The Institute of International Finance says world debt reached $318 \%$ of GDP at the end of 2017, 48 percentage points higher than the pre-Lehman peak. Emerging market debt has jumped from $145 \%$ to $210 \% "$.

Driven by financialization, the centrifugal forces ripping apart not just the BRICS but in fact all of contemporary world capitalism - first globalizing, now deglobalizing - can be traced back to the metabolism of economic cycles yielding ever more intense bursts of crises since the economic stagnation first hit the US, Europe and Japan in the 1970s. The 2008 crisis delivered a rude shock within this long cycle (as had the traumatic 1998-2001 period for Russia, South Africa and Brazil), for even the everhigher levels of world debt and the central banks' loose-money strategies have proven unable to restore either growth and debt ratios to previous levels. It was initially hoped that, as the Financial Times put it in 2010, these 'building BRICs' would 'change the economic order' by marshalling both their own raw resource production and manufacturing capacity to, in turn, achieve sufficient weight to reduce unfairness in world trade and finance ${ }^{6}$.

But against such overblown theories of virtuous-cycling centripetal capitalism, whether from $\mathrm{Xi}$ or the $F T$, the centrifugal contradictions manifest in over-production, over-indebtedness and deglobalization appear to be ending those fantasies. The only recent relief came from the Chinese state's massive urban construction investments (leaving scores of near-empty cities), perhaps to be repeated through its Belt and Road Initiative in coming years, as well as India's service sector-led boom. But the other three BRICS suffered recessions once the 2015 commodity price crash hit home, with South Africa not yet emerging into positive per capita GDP growth even in 2018. Under these circumstances of extreme intra-BRICS unevenness, Xi's centripetal strategy has become a centrifugal force spiraling out of control.

$\mathrm{Xi}$ and other Chinese leaders committed to pro-corporate globalization expect that their Belt and Road mega-infrastructure will push manufactured exports and pull energy imports through a restructuring Eurasia. But the BRICS' financial short-term fixes massive debt and stock market speculation - continue, too, as stock markets bubble in South Africa (today 90\% higher than in 2010), India (70\%) and Russia (50\%). China's stock exchanges were in the same league, but just as the yuan was made an IMF-acceptable global currency reserve, the Chinese markets lost more than $\$ 5$ trillion in two share bubble bursts in 2015-16.

Within this general decline in global flows, FDI inflows to the BRICS countries were still net positive, but as overaccumulation crisis hit China and overcapacity levels reached critical mass, FDI stocks of outflows rose by $21 \%$ in 2016 to $\$ 2.1$ trillion.

${ }^{5}$ Evans-Pritchard A. A worldwide financial storm is brewing as central banks pick their poison. Sydney Morning Herald, 18 June 2018. URL: https://www.smh.com.au/business/the-economy/ a-worldwide-financial-storm-is-brewing-as-central-banks-pick-their-poison-20180618-p4zm36.html (accessed 14.07.2018).

${ }^{6}$ Warrell H., Bernard S. Building BRICS: Changing the economic order. Financial Times, 15 January 2010. URL: http://ig-legacy.ft.com/content/f246692e-01cf-11df-b8cb-00144feabdc0\#axzz4qwyjnZaE (accessed 14.07.2018). 
[World Investment Report... 2017: 18] China became a net outward direct investor in 2016, and the second largest global investor (after the U.S.), accounting for $\$ 183$ billion in outward FDI. According to the World Investment Report 2017 "Chinese multinational enterprises invested abroad to gain access to new markets and to acquire assets that generated revenue streams in foreign currency" [World Investment Report... 2017: 14]. But global governance cannot address the conditions for restored capital accumulation, not if the past decade of reforms continues, in part because of the way BRICS are amplifying the contradictions.

\section{MULTIPOLARITY RELEGITIMIZES IMPERIALISM}

The standard argument of multilateral optimistists was offered in 2016 by former Director of the Organization for Economic Co-operation and Development's Development Co-operation Directorate, Richard Carey: 'The fact that the BRICS are such strong supporters of the G20 and of the 2015 United Nations agreements is no small matter. It is a highly significant evolution, reflecting the emergence of a multipolar international system which has made possible the striking shift from an era of ubiquitous NorthSouth conflict to the current universal agreements in the UN development fora, on the basis of common objectives and differentiated responsibilities'[Carey 2016].

But while demanding reforms in the Bretton Woods financial institutions, specifically concerning voting quotas at the IMF during 2010-15, in the course of which the BRICS committed \$75 billion in recapitalization (of which more than half came from China), BRICS leaders also created their own new institutions. At the 2014 Fortaleza summit, the New Development Bank (NDB) was initiated to finance infrastructure, and the Contingent Reserve Arrangement (CRA) was built to lend to countries facing balance of payment problems. For those who considered the BRICS challengers to status quo neoliberal ideology, to U.S. economic supremacy and to the postwar world financial order sustained by World Bank and IMF, there was initially great optimism in 2013-14 [Bello 2014] [ $^{7}$.

However, the leading NDB personnel were drawn from the most conservative elements within the five countries' pool of financiers (with the brief, partial exception of Brazil during Workers Party rule). The NDB operational arrangements mimicked those of the World Bank and other multilateral banks, even to the extent of explicit staff sharing and project co-financing arrangements in 2016-18 memoranda of understanding. And by 2018, notwithstanding rhetoric about sustainable lending cribbed from its advisors Joseph Stiglitz and Nick Stern, the NDB's non-consultative strategies led to credits for conflict-ridden, environmentally-damaging projects (e.g. a controversial irrigation scheme in India and expansion of the Durban port-petrochemical complex). The NDB's social-environmental framework seek to differentiate responsibilities by giving a greater role to the borrowing States' national socio-environmental protection

${ }^{7}$ Desai R. The BRICS are Building a Challenge to Western Economic Supremacy. The Guardian, 2 April 2013. URL: https://www.theguardian.com/commentisfree/2013/apr/02/brics-challenge-westernsupremacy (accessed 14.07.2018). 
and risk management systems (the so-called 'country system') $)^{8}$. On the one hand, the policy of strengthening national systems complies with principles of non-interference in internal affairs and thus preserves the scope of action of national states, unlike policies pursued by traditional multilateral financial institutions such as the World Bank. On the other hand, there is a risk that the bank will precipitate a widespread downgrading of standards given the lack of environmental and social safeguards that were already won in struggles with other multilateral banks. Notably, these standards are left for national institutions to decide, implement and monitor, without the responsibility for lack of transparency, public consultation, human rights violations, corruption and environmental disasters. Consequently, national social-environmental standards may be put to global competition to attract investors [Esteves 2018].

Moreover, although the CRA facility has not been drawn down - mainly because Brazil, Russia and South Africa exited their respective 2015-17 recessions without (yet) suffering a foreign debt repayment crisis - the CRA actually strengthens IMF leverage. The CRA articles of agreement compel any borrower to acquire an IMF structural adjustment package after receiving just $30 \%$ of its lending quota (in order to access the next 70\%). And as for IMF voting reform, the new investments raised by the BRICS had the effect of disempowering most poor countries by lowering their ownership share (e.g. Nigeria and Venezuela by $41 \%$ and even South Africa by $21 \%$ ), so that China's could rise by $37 \%$, Brazil's by $23 \%$, India's by $11 \%$ and Russia's by $8 \%$. In contrast, in the 2018 World Bank recapitalization, Russia deigned to participate, as it was under Crimea-related sanctions and hence not eligible to borrow from the Bretton Woods Institutions. As for the benefits of a greater 'voice,' the BRICS directors failed to promote a candidate for managing director from within, as they not only voted unanimously for the French conservative finance minister Christine Lagarde in 2011, but in 2015 extended her term and even approved continuance of her controversial reign in 2016 on the day she was convicted in French courts of negligence in a \$430 million corruption scandal. During this period, there was no change in the neoliberal Washington Consensus philosophy that has proven so adverse to poor economies, societies and environments.

With respect to trade, at the 2015 Nairobi WTO summit, agricultural subsidies and hence food sovereignty were slated for abolition, thanks to crucial alliances made between negotiators from Washington and Brussels, facilitated by Director General Roberto Carvalho de Azevêdo, a Brazilian. To the dismay of many observers the deadlock that had characterized the WTO over the prior dozen years was broken, mainly by the Brasilia and New Delhi representatives, with China, South Africa and Russia compliant ${ }^{9}$. This gave some credence to Xi's celebrated World Economic Forum speech two years later, deploying what might well have been the most hackish pro-market rhetoric ever heard in Davos.

${ }^{8}$ BRICS New Development Bank. Environmental and Social Framework. Shanghai, 2016. URL: http://ndb.int/pdf/ndb-environment-social-framework-20160330.pdf (accessed 14.07.2018).

9 Chagravati Raghavan Doha SU Diminished, not Dead, and Retrievable. Third World News Network, 23 December 2015. URL: http://www.twn.my/title2/wto.info/2015/ti151222.htm (accessed 14.07.2018). 
The problems troubling the world are not caused by economic globalization... Any attempt to cut off the flow of capital, technologies, products, industries and people between economies, and channel the waters in the ocean back into isolated lakes and creeks is simply not possible... We must remain committed to developing global free trade and investment, promote trade and investment liberalization. We will expand market access for foreign investors, build high-standard pilot free trade zones, strengthen protection of property rights, and level the playing field to make China's market more transparent and better regulated... China will keep its door wide open and not close $\mathrm{it}^{10}$.

The reality was different, for starting in mid-2015, Beijing had imposed stringent exchange controls, stock market circuit breakers and financial regulations to prevent two Chinese stock market collapses from spreading (beyond $\$ 5$ trillion in estimated losses). Beijing's measures included arrest of nearly 200 people 'for spreading rumours online' - but these efforts in mid-2015 did not prevent an $8 \%$ crash in two days in January 2016. Moreover, within 18 months of his speech, Xi authorized a set of trade restrictions on U.S. products in retaliation for Trump's protectionist tariffs.

With respect to the other main UN reform at the global scale, in late 2015 the BRICS signed the Paris Climate Accord, but did so mainly because it is non-binding, unambitious and outlaws climate-debt lawsuits by victims of Western and BRICS emissions. More evidence of assimilation was provided at the July 2017 G20 summit in Hamburg, where BRICS leaders were even more callous about the economic damage to poorer countries they are inflicting in alignment with the G7 (and especially the G1). A genuinely anti-imperialist climate change strategy would have entailed, at minimum, a global carbon tax, with an initial focus on the U.S. ${ }^{11}$

After the 2017 G20 summit, at least three seasoned political economists who in the past had firmly favoured the BRICS appeared to reverse positions. According to Ravi Kanth of the influential Malaysian NGO Third World Network, 'For the first time, the Doha Development Agenda (DDA) or the unresolved Doha issues were not even mentioned in the G20 leaders' communique because of opposition from the United States as well as other major industrialized countries. China, India, Brazil, South Africa, and Indonesia who negotiated the Hamburg declaration along with their developed country counterparts seemed to have allowed the erasing of DDA' (i.e. which Kanth considers meets poorer countries' balanced trade interests) ${ }^{12}$. Others went further. Yash Tandon, former head of the South Centre, claimed: 'At the G20 Hamburg meeting, Africa was officially represented by only one country - South Africa, which was obsequiously behaving like a neo-colony that it is ${ }^{\prime 13}$. And the Filippino founder of Focus

10 Xi Jinping Delivers robust Defense of Globalization at Davos. Financial Times, 17 January 2017, with full speech online at URL: https://america.cgtn.com/2017/01/17/full-text-of-xi-jinping-keynoteat-the-world-economic-forum (accessed 14.07.2018).

11 Inman Ph. Sky-high Carbon Tax needed to avoid Climate Catastrophe, say Experts. The Guardian, 29 May 2017. URL: https:/www.theguardian.com/environment/2017/may/29/sky-highcarbon-tax-needed-to-avoid-catastrophic-global-warming-say-experts (accessed 14.07.2018).

12 Kanth R. Developing and LDCs to pay Heavy Price for Hamburg Declaration. South North Development Monitor. 11 July 2017. URL: http:/www.twn.my/title2/wto.info/2017/ti170709.htm (accessed 14.07.2018).

13 Yash Tandon G20: The Second Berlin War against Africa. Pambazuka News, 20 July 2017. URL: https://www.pambazuka.org/printpdf/97301 (accessed 14.07.2018). 
on the Global South, Walden Bello, concluded that the whole export-oriented development strategy had reached a dead end:

The stagnation of the once dynamic centers of the global demand - the U.S., Europe, and the BRICS - has made this model obsolete. It was, in fact, the non-viability of this once successful model of rapid growth in current global circumstances that pushed China, under $\mathrm{Hu}$ Jintao and Wen Jiabao, away from an export-oriented path to a domestic demand-led strategy via a massive $\$ 585$ billion stimulus program. They failed, and the reason for their failure is instructive. In fact, a set of powerful interests had congealed around the export-oriented model' [Bello 2017].

\section{BRICS CORPORATIONS CONTRIBUTE TO CENTRIFUGAL UNDERDEVELOPMENT}

Those interests overlap with the status of the BRICS' own 'unpatriotic bourgeoisies,' including allies of multinational corporations. Such firms are responsible for the BRICS suffering a major outflow of legal (not just illegal) profits, relative to inflows of profits from the countries' own firms doinb gusiness abroad. In 2015, the South African Reserve Bank recorded net profit flows from abroad ranging within three broad categories: above $100 \%$ were Western countries; in the $15-60 \%$ range were large middle-income countries; and below $15 \%$ were poor, exploited countries. The BRICS were all in the $18-20 \%$ range, except South Africa whose ratio was closer to $45 \%$ (Figure 2).

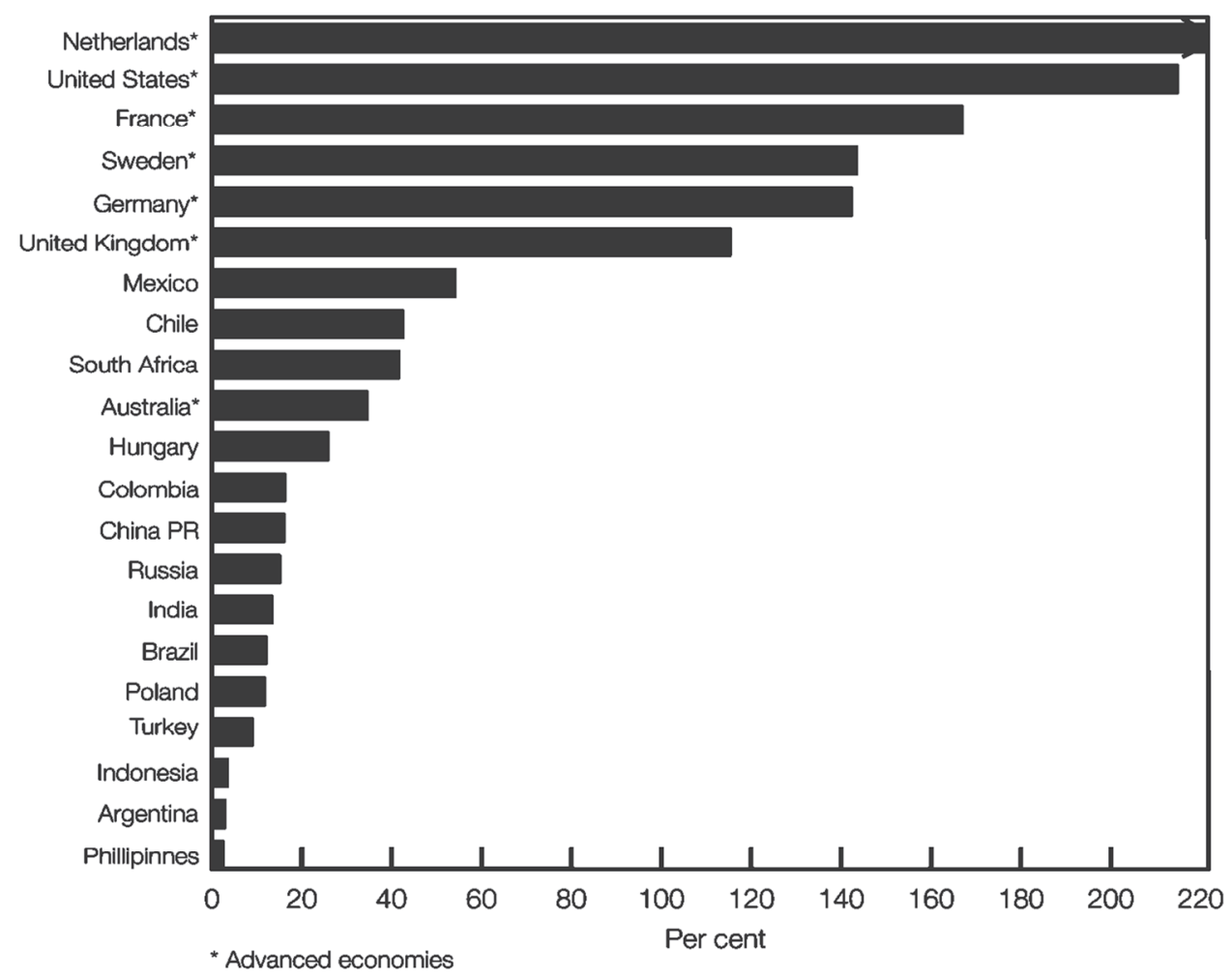

Fig. 2. Net profit flows - in the form of dividend receipts/payments, 2012-14

[Quarterly Economic Bulletin 2015: 39] 
This is a consistent indicator of the surplus extraction process, although corporate misinvoicing and other tax dodges make both the inflows and outflows to and from the BRICS even greater than formally recorded. The United Nations Economic Commission for Africa estimated that $\$ 319$ billion was transferred illicitly from Africa during the commodity super-cycle, from 2001 to 2010. The United States was the leading single destination for this hot money with $\$ 50$ billion in inflows; but China, India and Russia were together responsible for $\$ 59$ billion (Brazil is not recorded in the top 17 and South Africa is not included) [Mevel, Ofa, Karingi 2013]. BRICS countries are also five of the top seven countries to lose Illicit Financial Flows, at a rate from 2004-13 of $\$ 340$ billion annually [Kar, Spanjers 2015].

Following the brief 2009-11 post-crisis commodity boom — mainly driven by China's mega-project infrastructure projects (including its infamous ghost cities) commodity prices peaked, and in 2015 crashed by more than $50 \%$ in most sectors, led by minerals. This had an especially damaging role on commodity exporters' current account balances and ability to repay foreign debt. Chinese contributions to both fixed capital and financial capital inflows waned in most of the major borrowing countries. With commodity prices recovering in 2016 - 18 but still very far from levels the potential for China to collect collateral is already becoming a source of potential conflict among the BRICS.

Certainly, China's period of 'non-interventionism' appears to be ending. This is evident in Zimbabwe, where Beijing's military command played a vital role in the coup that ended Robert Mugabe's presidency in November 2017 [Bond, Saunders 2005]. The Chinese relationship with the local army included $\$ 15$ billion in allegedly missing diamonds (according to even Mugabe in 2016). The other BRICS also appear to be supporting a relatively liberalized agenda — including increased imposition of bilateral investment deals - that will further weaken most poor countries' economic resilience in a world economy careening out of control.

\section{THE BRICS JOHANNESBURG SUMMIT}

The BRICS met in Johannesburg in July 2018 just as Donald Trump was jerking Western imperialism out of traditional alignments. With war-talk against Iran blowing through Trump's tweets, and with Washington's trade wars raging against both China and traditional allies, as well as tightened sanctions against Russia, there was an expectation for some counter-hegemonic movement. But the BRICS failed to stand up to Trump, mainly due to their ideological diversity, given that several pro-Washington leaders offset $\mathrm{Xi}$. An excellent opportunity to establish a firmly oppositional stance against Washington was utterly wasted.

The only apparent unity came from the elites' love of mercantilist-neoliberalism. As Ramaphosa put it, 'We confirmed our commitment to the World Trade Organization, as the most effective mechanism available to ensure a rules-based transparent, nondiscriminatory, open and inclusive multilateral trading system'.

Hope for counter-hegemonic finance was also raised, but an alternative credit ratings agency (RA) did not materialize — in spite of Brazil, Russia and South Africa suffering junk ratings from Standard \& Poors, Fitch and Moody's. Worse, the BRICS Expert 
Group report on a new RA suggested features that recreate in such a body many of the three agencies' same foibles. That Expert Group recommended, 'The BRICS RA shall adopt the issuer-pay business model since it is well-tested and globally accepted. The BRICS RA should be set up as a private sector entity to ensure private-sector efficiencies, independence from government influence, credibility and acceptance by global investors... On the governance and operational aspects, too, private-sector efficiencies can be derived to ensure commercialization on market-based principles'. How is this different from the standard neoliberal demands of the existing RAs?

RA technical advisers will be important: 'The expert group suggests a voluntary network of well-established credit rating agencies registered in each of the BRICS nations be formed'. In short, as in so many aspects of its work, the BRICS bloc starts with rhetoric about an 'alternative' to Western hegemony and ends up amplifying neoliberal capitalism instead.

\section{BRICS-FROM-BELOW GRIEVANCES AND PROTESTS}

The main site to consider antidote analysis and news is 'BRICS from below,' a tradition of counter-summit critique begun in Durban five years ago, and also witnessed in Fortaleza in 2014, Goa in 2016 and Hong Kong in 2017. [Bond 2013] In 2015, Russia's Ufa proved an impossible site in which to generate civil society critiques, and instead Putin established a 'Civil BRICS' hand-in-hand with Oxfam to draw activists inside. The annual counter-summit activity included a Teach In at the University of the Witwatersrand and two protests: one at the Sandton summit led by the United Front-Johannesburg and the other at the BRICS New Development Bank (NDB) regional branch nearby. The former, on 26 July, raised the variety of critiques now increasingly common against BRICS states and companies: exploitation and unemployment, climate change and pollution, violence against women, repression and surveillance, non-delivery of services, austerity, budget cuts, human rights abuses, rampant corruption, racism, xenophobia, extreme inequality, looting of natural resources, sub-imperialism, neoliberalism, dictatorships and homophobia. There were especially angry delegations representing Kashmiris, Rwandans and Congolese. Indeed the Muslim Lawyers Association managed to get a docket initially investigated by Pretoria's National Prosecuting Authority for the Indian regime's gross human rights abuses in Kashmir, but one of Ramaphosa's most trusted ministers ensured it was quashed a few days before the visit.

The other protest, against the NDB on 25 July, was led by four Goldman Environmental Prize winners and their organizations and allies: Makoma Lekalakala of Earthlife Africa, Bobby Peek of ground Work, Thuli Makama of Oil Change International and Des D'Sa of the South Durban Community Environmental Alliance. They mainly raised the vexing questions of socio-ecological damage and corruption associated with the mega-projects typically announced with fanfare at the BRICS summits, and now increasingly financed by the NDB [Bond 2016]. Indeed, a huge increase in coal-fired power plant financing resulted from the biggest single loan announced during the BRICS summit: the China Development Bank's US \$2.5 billion credit to complete the stateowned power company Eskom's generators at Kusile, in Mpumalanga still mired in corruption and missed deadlines. With its 4800 megawatts of supply, Kusile will emit 31 million tonnes of $\mathrm{CO}_{2}$ annually, one of the world's most carbon-intensive power plants. 
Following a major 2009_-11 campaign against World Bank and US Ex-Im Bank financing of Eskom's coal generator expansion (focused on Kusile's predecessor Medupi power plant), the leading pollution watchdog ground Work has called for further Kusile work to be halted. Again, corruption is a factor. In 2015, the US Securities and Exchange Commission fined Hitachi US \$19 million for violating the Foreign Corrupt Practices Act, specifically for making 'improper payments' to South Africa's ruling party when bidding to install coal boilers worth US \$5.6 billion. But Hitachi's work continues at Kusile, with no South African prosecution. On top of that, the NDB reactivated a US \$180 million for restructuring Soweto's electricity grid plus privatized renewable grid lines. The first is opposed by Soweto community activists led by decommodified-electricity activist Trevor Ngwane, on grounds it will end up squeezing local consumers.

The NDB energy grid loan to Eskom is also being fought by the country's largest trade union - the National Union of Metalworkers of South Africa - because it will prevent progress towards a socially-owned, worker-managed renewables sector. Metalworker leader Irvin Jim argues instead for a non-profit strategy of energy based on 'decentralized ownership and operation integrated into a coherent, national centre. We made it clear that the national grid must be publicly owned and must remain the backbone of energy provision.' Instead, the NDB promotes the Independent Power Producer model, which, says Jim, is 'the privatization of Eskom by other means and we reject it in its totality. We cannot allow the grid and the supply of electricity to be placed in private hands. We have learnt many hard lessons in the past about privatization. It ultimately worsens conditions for workers and their families, through increased tariffs and retrenchments.'

Transnet also received a recent US \$200 million loan from the NDB, to finance the expansion of the Durban port-petrochemical complex. It is firmly opposed by D'Sa and his organization for reasons ranging from the borrower's prolific corruption to its insensitivity to climate change to the anticipated rise in local pollution and housing displacement. At least D'Sa and much more of South African society breathed a sigh of relief at one announcement, regarding the largest proposed mega-project made at prior BRICS summits in 2014 and 2015: US \$100 billion worth of nuclear energy reactors. That deal, between former South African president Jacob Zuma and Putin, is now on indefinite hold. As Ramaphosa explained, 'On nuclear, we said because our economy is not participating at a level we would like it to and have huge financial constraints, we are not able to proceed with a nuclear build programme. President Putin was relaxed about this and says that we (must) deal with our issues, and when the situation changes we can talk and that's where we left it.

This was one of several diplomatic stresses. Another occurred during the main symbolic event for the five leaders: visiting the 'Cradle of Humankind' where some of the world's oldest hominids (four million years) have been preserved. At the last moment the visit was replaced with what should have been a live video feed from the site (an hour west of Johannesburg). Ramaphosa admitted, 'The logistical arrangements 
were a little difficult for us' (to get to the Cradle site). Then, to everyone's embarrassment, the video feed also failed. As a journalist observed, 'There were so many logistical failures that it was ironic for the leaders to discuss the 4th Industrial Revolution as part of their future plans'. Most enthusiastic was Survé: 'I have a vision, as a South African, African and internationalist, that our continent will thrive, that millions of unemployed youth will be educated with the skills required for the 4IR'. The 4IR concept fuses Artificial Intelligence, robots, nano-technology and all manner of other dangerous, disparate high-tech corporate and state innovations, resulting in massive job losses, enhanced surveillance (e.g. China's 'Social Credit') and potential chaos if not regulated and socially controlled. The ironies of the BRICS are here encapsulated, for they begin with the critique everyone shares of a world out of control, one facing myriad geopolitical, economic and environmental meltdowns - and end with even more contradictions. Now, with Trump setting the agenda on the building and destruction of political alliances between states while wrecking prospects of multilateral action, the world requires a new generation of international leaders to develop a genuine alternative. That can only occur based not on the desire to merely gain a seat at the global corporate capitalist table, as do the BRICS elites, but on overturning it.

\section{CONCLUSION}

The nefarious effects of neoliberal globalization have pushed the world into uneven economic crisis, whose political consequences are also uneven. The new far-right politicians, parties and movements have come to power either through democratic or more dubious ways, with the 2016 parliamentary coup in Brazil an example of the latter. Curiously, Trump's election in the U.S. and his shift towards economic protectionism places China in a new position: leading defender of open markets and globalization, notwithstanding its own powerful tools of protectionism and regulation. Thus, the international Left faces a paradoxical situation: anti-globalization discourses - which, a few years ago, shaped transnational liberatory struggles against the multilateral institutions, perhaps most famously the Seattle WTO summit of 1999 - emanate from the extreme right, alongside the xenophobia and racism that are anathema to the left. And although many observers were understandably confused in the early years of the BRICS, today, as their governments have become promoters of home corporations above all, it is impossible to talk about a real alternative for a fairer world order coming from the BRICS' ruling elites.

Although battling the BRICS is far removed from the reality of social movements in each of these countries (Johannesburg in 2018 being a case in point), this may change as BRICS institutions, especially the NDB, reinforce the environmentallypredatory development model that destroys their territories' natural life and the work of their peoples. In other words, international solidarity and processes of articulation and strengthening of 'BRICS from below' will take place in the inevitable processes of struggle, with the challenge ahead being — as everywhere — to connect the dots and identify sites of structural weakness for insurgent opportunities. 


\section{REFERENCES}

Bello, W. (2014). The BRICS: Challengers to the Global Status Quo. Foreign Policy in Focus, 29 August 2014. URL: https://fpif.org/brics-challengers-global-status-quo/ (accessed 14.07.2018). Bello, W. (2017). It's Not Only Necessary to Develop an Alternative to Globalization - It's Entirely Possible. Foreign Policy in Focus, 19 July 2017. URL: http://fpif.org/its-not-only-necessaryto-develop-an-alternative-to-globalization-its-entirely-possible/ (accessed 14.07.2018).

Bond, P. (2013). Sub-imperialism as Lubricant of Neoliberalism: South African 'deputy sheriff' duty within BRICS. Third World Quarterly, 34 (2), 251-270. DOI: https://doi.org/10.1080/ 01436597.2013.775783.

Bond, P. (2016). BRICS banking and the debate over sub-imperialism. Third World Quarterly, 37(4), 611-629. doi:10.1080/01436597.2015.1128816

Bond, P. \& Garcia, A. (Eds.). (2015). BRICS. An anti-capitalist critique. Johannesburg: Jacana Media.

Bond, P. \& Saunders, R. (2005). Labor, the State, and the Struggle for a Democratic Zimbabwe. Monthly Review. URL: https://monthlyreview.org/2005/12/01/labor-the-state-and-the-strugglefor-a-democratic-zimbabwe/ (accessed 14.07.2018).

Carey, R. (2016). The BRICS Role in Today's Multipolar World. Institute for Development Studies. URL: https://www.ids.ac.uk/opinion/the-brics-role-in-today-s-multipolar-world (accessed 14.07.2018).

Esteves, P. (2018). Preface. In: Country Systems and Environmental and Social Safeguards in Development Finance Institutions: Assessment of the Brazilian System and Ways Forward for the New Development Bank. Sao Paolo: Conectas Direitos Humanos, p. 11-15. URL: https://rightsindevelopment.org/wp-content/uploads/2018/05/Conectas_Country_Systems_ DFIs_Brazil_NDB-Final.pdf (accessed 14.07.2018).

Kar, D. \& Spanjers, J. (2015). Illicit Financial Flows from Developing Countries, 2004-13. Washington DC. URL: http://www.gfintegrity.org/wp-content/uploads/2015/12/IFF-Update 2015-Final-1.pdf (accessed 14.07.2018).

Mevel, S., Ofa, S. \& Karingi, St. (2013). Quantifying Illicit Financial Flows from Africa Through Trade Mis-Pricing and Assessing Their Incidence on African Economies. United Nations Economic Commission for Africa presentation to the African Economic Conference. Johannesburg, 28-30 October 2013. URL: http://www.afdb.org/en/aec/papers/paper/quantifying-illicitfinancial-flows-from-africa-through-trade-mis-pricing-and-assessing-their-incidence-on-africaneconomies-945 (accessed 14.07.2018).

Stevens, J. (2018). Africa Macro: The BRICS Summit. Standard Bank Resaearch Brief. Johannesburg. URL: https://research.standardbank.com/ResearchPortal/Preview.action?showPage=\&id= 0a4f61 f0-9e88-4e98-b21c-43ee67b18d94 (accessed 14.07.2018).

Quarterly Economic Bulletin. (2015). South African Reserve Bank, 256.

World Bank Data Catalogue. (2018). URL: https://data.worldbank.org/indicator/NE.TRD.GNFS.ZS? end $=2017 \&$ locations $=$ CN-BR-ZA-IN-RU-1W\&start=1997\& $\mathrm{view}=$ chart $($ accessed 14.07.2018).

World Investment Report 2017. (2017). UNCTAD. URL: https://unctad.org/en/pages/Publication Webflyer.aspx?publicationid=1782 (accessed 14.07.2018).

World Investment Report 2018. (2018). UNCTAD. URL: http://unctad.org/en/PublicationsLibrary/ wir2018_en.pdf (accessed 14.07.2018).

Received: 15.08 .2018

For citations: Bond, P. (2018). The BRICS' Centrifugal Geopolitical Economy. Vestnik RUDN. International Relations, 18 (3), 535-549. DOI: 10.22363/2313-0660-2018-18-3-535-549.

\footnotetext{
About the Author: Patrick Bond is Professor of Political Economy, University of the Witwatersrand, Johannesburg, South Africa (e-mail: pbond@mail.ngo.za).
} 
DOI: 10.22363/2313-0660-2018-18-3-535-549

\section{ЦЕНТРОБЕЖНАЯ ГЕОЭКОНОМИКА БРИКС}

\section{П. Бонд}

Университет Витватерсранда, Йоханнесбург, ЮАР

Статья посвящена анализу центробежных тенденций в рамках БРИКС и их влиянию на процессы, происходящие в глобальном масштабе. Пристальное внимание уделяется факторам, стимулирующим данные тенденции.

Автор полагает, что, несмотря на позитивный потенциал и заметную роль стран БРИКС в условиях глобальных кризисов, своей нынешней экономической политикой они способствуют продвижению «империализма», активизируя тем самым негативные проявления глобального «кризиса капитализма». По мнению автора, многополярность усиливает неолиберальный характер институтов, особенно в сфере финансов, торговли и климата. Корпорации, базирующиеся в странах БРИКС, демонстрируют сверхэкплуатацию в ходе накопления капитала, как в своих регионах, так и за пределами. Статья основана на осмыслении документов международных организаций, в том числе ЮНКТАД, критическом анализе мнений экспертов, разделяющих иногда противоположные взгляды.

Автор задается целью доказать, что движение в позитивном направлении возможно. Статья содержит призыв рассматривать итоги саммита БРИКС в Йоханнесбурге в 2018 г. как приглашение общественности стран - членов этой организации к серьезному совместному обсуждению проблем современной глобальной политики.

Ключевые слова: БРИКС, глобальная политика, корпорации, Йоханнесбург, саммит, многополярность

Дата поступления статьи: 15.08.2018

Для цитирования: Bond P. The BRICS' Centrifugal Geopolitical Economy // Вестник Российского университета дружбы народов. Серия: Международные отношения. 2018. Т. 18. № 3. С. 535549. DOI: 10.22363/2313-0660-2018-18-3-535-549.

Сведения об авторе: Патрик Бонд - профессор политической экономии Университета Витватерсранда, Йоханнесбург, ЮАР (e-mail: pbond@mail.ngo.za). 